\title{
Glandular (Acinar)/Tubular Differentiation Score 1
}

National Cancer Institute

\section{Source}

National Cancer Institute. Glandular (Acinar)/T ubular Differentiation Score 1. NCI

Thesaurus. Code C138975.

Greater than $75 \%$ of tumor area shows glandular/tubular structures. 